\title{
The Effect of Music on Anger and Stress in Elderly
}

\author{
Tugba Sari \\ Yozgat City Hospital, Yozgat, Turkey \\ E-mail: tubaaasari@gmail.com \\ Birgul Ozkan \\ Ankara Yildirim Beyazit University, Institute of Health Sciences, Ankara, Turkey \\ E-mail: bozkan@ybu.edu.tr
}

\begin{abstract}
This study is a systematic review on determining the effect of music on anger and stress in elderly. The study was conducted by checking Pubmed, Wiley Interscience, Google Scholar databases. A total of six articles that were compatible with the keywords were evaluated. According to the findings of the systematic review, music increases the sense of independence in the elderly. The feeling of independence is an important factor in increasing one's self-confidence. This allows the elderly to cope better with feelings of helplessness and depression. It has been stated that music has an effect of decreasing anxiety in elderly living in a nursing home. One of the most important problems in elderly is loneliness. In a study conducted in a nursing home, it was stated that there was a decrease in the perception of loneliness by the music that was played to the elderly. As a result, listening to music has a positive effect on diseases. As listening to music positively affects the anxiety, loneliness and comfort levels of elderly, it is recommended that music therapy should be used as a complementary treatment method in elderly care.
\end{abstract}

Keywords: Elderly, Anger, Stress, Music Intervention, Music Therapy

\section{Special Issue of Health Sciences}

DOI: $10.7176 / \mathrm{JSTR} / 6-03-30$

\section{INTRODUCTION}

The World Health Organization states that aging is a reduction in the ability to adapt to environmental factors (World Health Organization 1999). According to another definition, old age is defined as irreversible structural and functional changes by time progress at the levels of molecules, cells, tissues, organs and systems (Kutsal GY 2008). Elderly population ratio in Turkey is increasing. According to the data published by Turkey Statistical Institute; in 2016, the number of elderly population (age 65 and over) in our country was $6,624,634$ and it was determined as $8 \%$ of the total population. When the demographic structure of developed countries is considered, the ratio of 65 years and older population is over $10 \%$ and in less developed countries it is 5\%. According to the World Health Organization (WHO) report on "aging and health" in 2015, it is expected that the population aged 60 years and over, which is still 962 million worldwide, will increase more than threefold and increase to 3.1 billion until 2100 (WHO 2018). In the aging process, heredity, lifestyle, working conditions, nutritional characteristics, chronic diseases and personality traits are effective and 65 is considered as old age limit (WHO 1984). Aging is physiologically; the progression of age at the biological level and the widespread deterioration of body functions as a result of molecular and cellular damage, weakness against changing environmental conditions and increased risk of disease and death (Kirkwood TB 2008). In the psychological aspect of old age, there are cognitive behavioral changes. Changes in areas such as cognitive skills are attention, learning, memory, language, reasoning; psychological behavior changes are affect mood, motivation and coping skills (Göka E; Aydemir Ç 2000). The change in body with aging, the deterioration of the organ functions and physical image cause different psychological reactions in each individual (Bahar A 2007). In the elderly people who show centripetal behaviors, there is a decrease in emotional quality and quality of life, such as self-esteem, self-love, life force and desirability. Elderly people, whose emotional state is greatly affected, show extreme sadness in the face of minor events (Koç M 2002). There are negative 
psychological effects in elderly due to various losses. In this context, the elderly are thought to be in a more peaceful period, they experience a lot of stress.

The decrease in sociality, the sense of loneliness, economic and physical deficiencies, the decrease in self-esteem, the lack of self-confidence in self-efficacy, the loss of one of the spouses, the decrease in self and self-esteem, the use of many drugs are among the risk factors that cause the elderly to experience stress (Yüksel N 1998). With the advancement of age, concerns about the future in elderly individuals, not feeling safe and the limitations of age, cause frustration and anger. The feeling of being treated as disrespectful or unfair to others, the tension in family and marital relations, and the feeling of being rejected by family, friends and society also cause frustration and anger (Morgan Clifford T 2006). Considering the reasons of the increase in the elderly population and the average life expectancy both in the world and in our country; by the scientific and technological developments in the field of health, it is seen that early diagnosis, prevention and treatment of diseases, decreased infant and child mortality as a result of the development of preventive health services, social conditions such as nutrition, shelter, hygiene have improved and positive effect on the health of individuals has increased with the level of education (Görgülü Ü; Akyar I; Akdemir N; et al 2010). Nurses constitute the most needed occupational group in elderly care.

Elder care nursing (Geriatric Nursing); help the elderly to self-care, cope with their emotional problems, be self-sufficient and live with their deficiencies and help them to feel valued (Kocataş S; Güler G; Güler $\mathrm{N}$ 2004). Nurse plays an important role in the evaluation of the needs of the individuals by evaluating the social support resources that will protect the mental health and the quality of life in order to increase the satisfaction and the quality of life of the elderly (Aksüllü N; Doğan S 2004). Psychiatric nursing has an important place in psychosocial examination of the elderly person. It enables the elderly to express their feelings by evaluating them spiritually and helps the individual to gain and maintain decisionmaking skills.

\section{The Effect of Music on Anger and Stress}

Music is of great importance for human physical and spiritual development, cultural maturity and civil living (Yener Alkaya Y 2011). It is constantly emphasized that music has a psychological impact on people and it is stated in scientific evidence that this effect is effective not only on people but also on other species. Music is highly influential in this aspect and has led scientists to use it for the treatment of psychological diseases in humans and to use them in animal studies for better efficiency (Sezer F 2011). Music has been used as a psychotherapy tool to improve self-esteem and body image, reduce depression, fear and abstraction and express their feelings clearly. It is an art that enables to express the emotions, thoughts and inner processes of human in the accompaniment of combined sounds and melodies (CoffinRomig NA 2012). To enable patients to communicate and gain confidence; to help them develop their ability to concentrate and express themselves. Especially when more positive atmosphere and calm music were played, it was observed that patients gave positive reactions. Music increases the sense of independence in the elderly. The feeling of independence is an important factor in increasing one's selfconfidence. This allows the elderly to cope better with feelings of helplessness and depression (Clair AA, Memmott J 2008). The treatment effect of music decreases the state of tension and irritability in the elderly who have emotional and stress-based problems (Yener Alkaya Y 2011).

\section{MATERIALS AND METHODS}

\section{Identification of studies}

The study was conducted by checking Pubmed, Wiley Interscience, Google Scholar databases. A total of six articles that were compatible with the keywords were evaluated. (Table 1)

Table 1. Identification of studies

\begin{tabular}{|l|l|}
\hline Elderly people & Music intervention \\
\hline Anger & Music therapy \\
\hline Stress & Elderly and music \\
\hline
\end{tabular}




\section{Study selection and data extraction}

In order to reach a high level of evidence, full-text articles in Turkish and English were included in the study. Other inclusion criteria were determined according to PICO (Population, Intervention, Comparison, Outcome). According to this;

- Only the older individuals

- Use of music application as an intervention,

- Making different kinds of music applications in the enterprises,

- This systematic review evaluates the effects of music intervention on decreasing the anger, stress, loneliness and depression levels and increasing comfort in elderly.

\section{Article selection}

The searches were conducted in Pubmed, Wiley Interscience, Google Scholar database and related headings / summaries $(n=65)$. Among the studies, those suitable for the purpose of the study were determined $(n=51)$. Duplicate studies were identified and screened $(n=8)$. After obtaining the full texts of the potential studies, the articles which were appropriate to the inclusion criteria were selected $(n=6)$. The selection process is as in Figure 1.

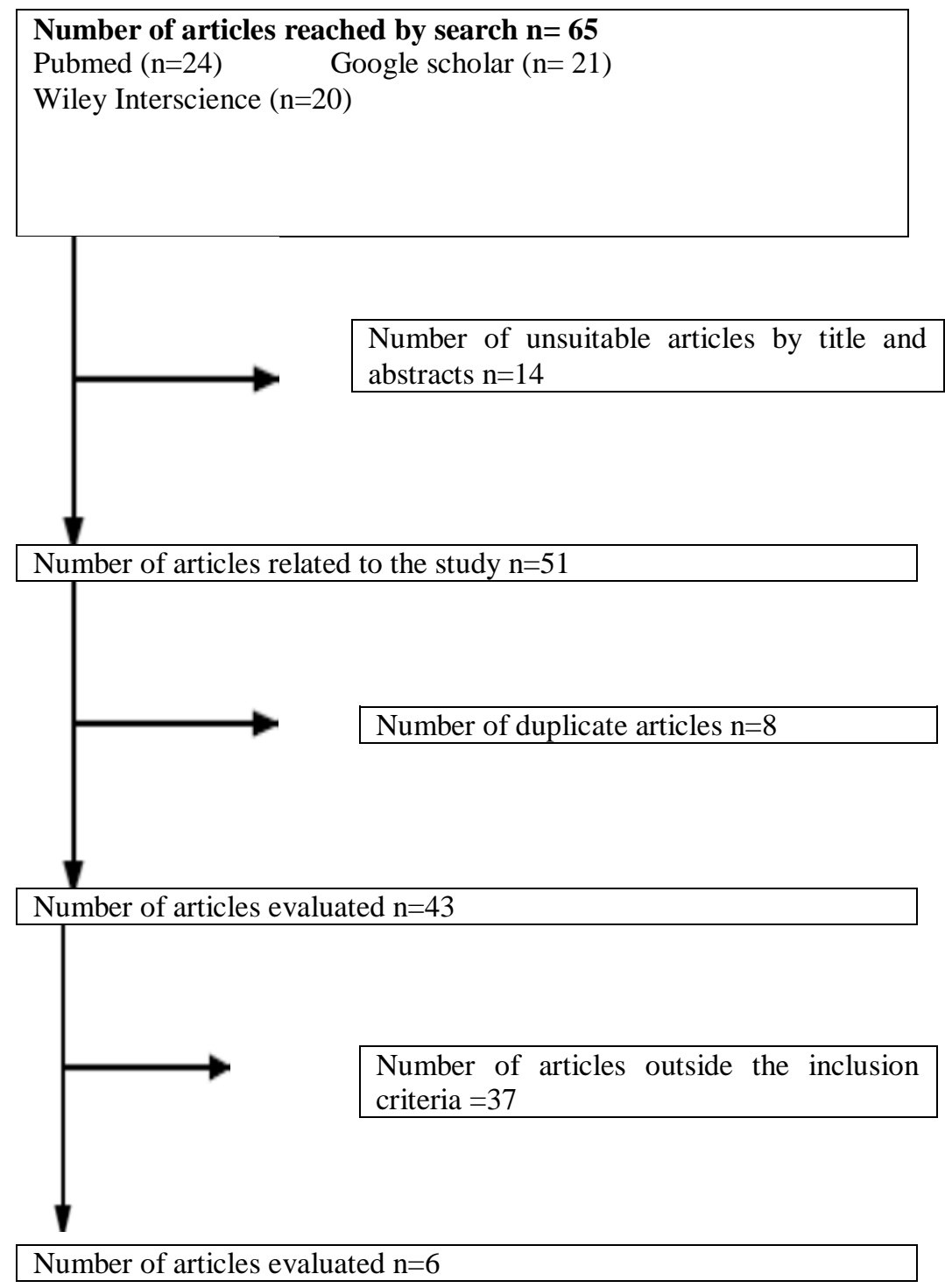

Figure 1. Compilation study selection process 


\section{RESULTS}

In this study, six research articles were examined. Four of the articles were written in English and two in Turkish. Researches were from Hong Kong, Italy, Taiwan and Turkey. Interventions have been studied systematically in the dimensions of stress, anxiety, loneliness and depression. Articles examined within the scope of the study are given in Table 2 .

Table II. Research methods and results

\begin{tabular}{|c|c|c|c|c|c|}
\hline Article & Objective & Author -Year & $\begin{array}{l}\text { Research Material } \\
\text { and Method Tools }\end{array}$ & Intervention & Result \\
\hline $\begin{array}{c}\text { Effects of music on } \\
\text { depression and sleep } \\
\text { quality in elderly } \\
\text { people: A randomised } \\
\text { controlled trial }\end{array}$ & $\begin{array}{l}\text { To investigate the } \\
\text { effect of music on } \\
\text { sleep quality, vital } \\
\text { signs and depression } \\
\text { levels in the elderly }\end{array}$ & $\begin{array}{l}\text { Moon Fai Chan, } \\
\text { Engle Angela } \\
\text { Chan, Esther } \\
\text { Mok (2010) }\end{array}$ & $\begin{array}{c}\text { Research } \\
\text { (Randomized } \\
\text { Controlled) } \\
\text { Pittsburgh Sleep } \\
\text { Quality Index, } \\
\text { Geriatric } \\
\text { Depression Scale }\end{array}$ & $\begin{array}{l}\text { Soft Slow } \\
\text { Music }\end{array}$ & $\begin{array}{c}\text { Soft and slow } \\
\text { music in the elderly } \\
\text { is indicated as an } \\
\text { intervention to } \\
\text { improve the quality } \\
\text { of depression and } \\
\text { sleep. }\end{array}$ \\
\hline $\begin{array}{c}\text { Exercise training and } \\
\text { music therapy in } \\
\text { elderly with } \\
\text { depressive syndrome: } \\
\text { a pilot study }\end{array}$ & $\begin{array}{l}\text { To determine the } \\
\text { effects of physical } \\
\text { education and music } \\
\text { therapy on mild to } \\
\text { moderate depression } \\
\text { against subjects } \\
\text { treated with } \\
\text { pharmacological } \\
\text { treatment only. }\end{array}$ & $\begin{array}{l}\text { Verrusio W., } \\
\text { Andreozzi P., } \\
\text { Marigliano B., } \\
\text { Renzi A., } \\
\text { Gianturco V., } \\
\text { Pecci M.T., } \\
\text { Ettorre E., } \\
\text { Cacciafesta M., } \\
\text { Gueli N. } \\
\text { (2014) } \\
\end{array}$ & $\begin{array}{c}\text { Research } \\
\text { (Randomized } \\
\text { Controlled) } \\
\text { Geriatric } \\
\text { Depression Scale }\end{array}$ & $\begin{array}{l}\text { Music } \\
\text { Therapy }\end{array}$ & $\begin{array}{l}\text { Exercise and music } \\
\text { therapy have been } \\
\text { found to reduce } \\
\text { anxiety symptoms } \\
\text { and depression and } \\
\text { show positive } \\
\text { effects in the } \\
\text { treatment of mild to } \\
\text { moderate } \\
\text { depression patients. }\end{array}$ \\
\hline $\begin{array}{c}\text { Effect of Turkish } \\
\text { classical music on } \\
\text { blood pressure: A } \\
\text { randomized controlled } \\
\text { trial in hypertensive } \\
\text { elderly patients }\end{array}$ & $\begin{array}{c}\text { To determine } \\
\text { whether classical } \\
\text { Turkish music has a } \\
\text { positive effect on } \\
\text { blood pressure and } \\
\text { anxiety levels in } \\
\text { elderly patients. }\end{array}$ & \begin{tabular}{|c|} 
Tansel \\
Bekiroğlu, \\
Nimet Ovayolu, \\
Yusuf Ergün, \\
Hasan Çetin \\
Ekerbiçer (2013)
\end{tabular} & $\begin{array}{c}\text { Research } \\
\text { (Randomized } \\
\text { Controlled) } \\
\text { Hamilton Anxiety } \\
\text { Rating Scale }\end{array}$ & $\begin{array}{c}\text { Classical } \\
\text { Turkish Music }\end{array}$ & $\begin{array}{l}\text { Both classical } \\
\text { Turkish music and } \\
\text { resting alone have } \\
\text { shown that it } \\
\text { positively affects } \\
\text { blood pressure and } \\
\text { anxiety levels in } \\
\text { hypertensive } \\
\text { patients. }\end{array}$ \\
\hline $\begin{array}{l}\text { Perceptions of group } \\
\text { music therapy among } \\
\text { elderly nursing home } \\
\text { residents in Taiwan }\end{array}$ & $\begin{array}{l}\text { To determine the } \\
\text { perception of group } \\
\text { music therapy in } \\
\text { elderly people living } \\
\text { in Taiwan nursing } \\
\text { home. }\end{array}$ & $\begin{array}{l}\text { Shu-Ling Chen, } \\
\text { Hui-Chuan Lin, } \\
\text { Sui-Whi Jane } \\
\text { (2009) }\end{array}$ & $\begin{array}{c}\text { Research } \\
\text { Mini-Mental State } \\
\text { Exam }\end{array}$ & $\begin{array}{l}\text { Music } \\
\text { Therapy }\end{array}$ & $\begin{array}{l}\text { It was emphasized } \\
\text { that music therapy } \\
\text { positively affects } \\
\text { elderly individuals } \\
\text { and increases their } \\
\text { quality of life and } \\
\text { health perceptions. }\end{array}$ \\
\hline $\begin{array}{c}\text { A Group Music } \\
\text { Intervention Using } \\
\text { Percussion } \\
\text { Instrumentswith } \\
\text { Familiar Music To } \\
\text { Reduce Anxiety And } \\
\text { Agitationof } \\
\text { İnstitutionalized Older } \\
\text { Adults With Dementia }\end{array}$ & $\begin{array}{l}\text { To determine the } \\
\text { effects of music } \\
\text { intervention on } \\
\text { anxiety and } \\
\text { agitation on elderly } \\
\text { individuals } \\
\text { diagnosed with } \\
\text { dementia. }\end{array}$ & $\begin{array}{l}\text { Huei-chuan } \\
\text { Sung, Wen-li } \\
\text { Lee, Tzai-li Li, } \\
\text { Roger Watson } \\
\text { (2012) }\end{array}$ & $\begin{array}{c}\text { Research } \\
\text { (Randomized } \\
\text { Controlled) } \\
\text { Cohen-Mansfield } \\
\text { Agitation Inventory, } \\
\text { Rating of Anxiety in } \\
\text { Dementia scale }\end{array}$ & $\begin{array}{l}\text { Music } \\
\text { Therapy }\end{array}$ & $\begin{array}{c}\text { Although there was } \\
\text { an anxiety-reducing } \\
\text { effect on the } \\
\text { elderly, there was } \\
\text { no major change in } \\
\text { agitation. }\end{array}$ \\
\hline $\begin{array}{l}\text { Effects of Passive } \\
\text { Music Therapy of } \\
\text { Sleep Quality in } \\
\text { Elderly in nursing } \\
\text { homes }\end{array}$ & $\begin{array}{l}\text { To determine the } \\
\text { effect of passive } \\
\text { music therapy on } \\
\text { sleep quality of } \\
\text { elderly people in } \\
\text { nursing home. }\end{array}$ & $\begin{array}{c}\text { Nihan Altan } \\
\text { Sarıkaya, Sidıka } \\
\text { Oğuz } \\
(2016)\end{array}$ & $\begin{array}{c}\text { Research } \\
\text { Pretest-posttest } \\
\text { Pittsburgh Sleep } \\
\text { Quality Index }\end{array}$ & $\begin{array}{c}\text { Classical } \\
\text { Turkish Music }\end{array}$ & $\begin{array}{l}\text { It has been stated } \\
\text { that passive music } \\
\text { therapy improves } \\
\text { sleep quality and } \\
\text { reduces stress. }\end{array}$ \\
\hline
\end{tabular}




\section{Sample selection}

The first article that was evaluated was evaluated by Chan et al. (2010) 's work. 42 elderly visited by Chan in their homes agreed to participate in the study. These individuals were randomly divided into two groups: 21 experiments and 21 controls. The next study was conducted by Verrusio et al. (2014). 24 people met the inclusion criteria. 24 elderly individuals were randomly divided into two groups: 12 experiments and 12 controls. Bekiroğlu et al. (2013) in the study of randomly 30 individuals and 30 control group consists of elderly individuals. Another study by Chen et al. (2009), focus group selection was made of 11 female and 6 male elderly. Sung et al. (2012) 's study consists of 60 elderly individuals, 30 experiment and 30 controls. Altan and Oğuz (2016) 's study had focus group of 31 elderly individuals.

\section{Effects of Music Practice on Elderly Individuals}

In a randomized controlled trial of 42 elderly individuals in Hong Kong, the music of their choice was played to the experimental group for 30 minutes for 4 weeks. Blood pressure, heart rate, depression levels and sleep quality were evaluated weekly. At the end of the study, it was determined that the level of depression decreased and the quality of sleep increased in elderly individuals. In this study, it was stated that music was an effective intervention method in the prevention of depression in elderly individuals (Chan MF; Chan EA; Mok E 2010).

Verrusio et al. conducted a study for six months in Italy, the experimental group was given exercise and music therapy as well as drug support, and as a result, anxiety symptoms and depression levels were found to be decreased and positive effects were observed (Verrusio W; Andreozzi P; Marigliano B; et al 2014).

Bekiroglu (2011) in his study played Classical Turkish Music to elderly people in the intervention group for 28 days, for 25 minutes in the nursing home. It has been determined that anxiety levels decrease in patients' blood pressure and anxiety levels before and after music sessions (Bekiroğlu T; Ovayolu N; Ergün Y; et al 2013).

Chen et al. (2009) made music therapy for 17 elderly people in a nursing home in Taiwan about 1 hour a week for 1 year. It was emphasized that music therapy positively affects elderly individuals and increases their quality of life and health perceptions (Chen SL; Lin HC; Jane SW 2009).

In a randomized controlled study conducted on 60 elderly individuals in a care center in Taiwan, 30 individuals in the experimental group performed a 30 minute music session twice a week for six weeks in the event room. At the end of the intervention, the level of anxiety was reduced in elderly individuals with dementia, but there was no significant change in agitation levels (Sung HC; Lee WL; Li T; et al 2012).

Another study in the nursing home also stated that people who had one hour of music intervention for 22 days sleep comfortably, have increased quality of sleep and have positive effects (Altan Sarkaya N; Oğuz S 2016).

The heavy tempo of classical Turkish music reduces the sympathetic nervous system activity and leads to relaxation by decreasing cortisol levels and increasing the secretion of biochemical mediators such as endorphins (Chlan LL 2000 \& Brody R 1984).

Music can reduce the physiological response to anxiety and stress in different ways, and can be used to synchronize various body rhythms such as breathing, heartbeat, speech and blood flow. For example, a relaxing, slow and flowing rhythm may reduce the sympathetic nervous system activity (Chlan LL 2000). The importance of treating with music and its contribution to healing patients were highlighted by Florance Nigtingale at the beginning of the 1800 s, and it was stated as a nursing intervention that reduced pain and anxiety and increased the comfort of patients (Khorshıd L; Akın E 2007).

As a result of listening to music it has a positive effect on diseases as specified in the literature. Listening to music positively affects the anxiety, loneliness and comfort levels of elderly people, it is recommended that the music therapy method should be extended to care of elderly individuals as a complementary treatment method.

\section{References}

Aksüllü, N., Doğan, S. (2004). Huzurevinde ve Evde Yaşayan Yaşlılarda Algılanan Sosyal Destek Etkenleri İle Depresyon Arasındaki İlişki. Anadolu Psikiyatri Dergisi, 5(2), 76-84.

Altan Sarıkaya, N., (2016). Oğuz, S. Huzurevinde Kalan Yaşlılarda Pasif Müzikoterapinin Uyku Kalitesine Etkisi. Journal of Psychiatric Nursing, 7(2), 55-60. 
Bahar, A. (2007). Kanser Hastalarına Psikososyal Yaklaşım. Atatürk Üniversitesi Hemşirelik Yüksekokulu Dergisi, 10: 1.

Bekiroğlu, T., Ovayolu, N., Ergün Y., et al. (2013). Effect of Turkish Classical Music On Blood Pressure: A Randomized Controlled Trial İn Hypertensive Elderly Patients. Complementary Therapies in Medicine, 21, 147-154.

Brody, R. (1984). Music Medicine. Omni, 6(24), 110.

Chan, M. F., Chan, E. A., Mok, E. (2010). Effects of Music on Depression and Sleep Quality in Elderly People: A Randomised Controlled Trial. Complement Ther Med, 18, 150-9.

Chen, S. L., Lin, H. C., Jane, S. W. (2009). Perceptions Of Group Music Therapy Among Elderly Nursing Home Residents İn Taiwan. Complementary Therapies in Medicine, 17, 190-195.

Chlan, L. L. (2000). Music Therapy As A Nursing Intervention For Patients Supported By Mechanical Ventilation. AACN Clin, 11(1), 128-138.

Clair, A. A. Memmott J. (2008). Therapeutic uses of Music with Older Adults. 2. Edition. N. Y., US: American Music Therapy Association.

Coffin-Romig, N. A. (2012). Therapies: Theory and Clinical Practice. In: Fortinash KM, HolodayWorret PA, Editors. Psychiatric Mental Healty Nursing E- Book. Fifth Edition. Printed in China, Elsevier Mosby, 597-619.

Göka, E., Aydemir, Ç. (2000). Yaşlıya Ve Demanslı Hastaya Psikososyal Yaklaşım. Demans Dergisi, 2(1), 5-26.

Görgülü, Ü., Akyar, İ., Akdemir, N., ve ark. (2010). Dünyada ve Ülkemizde Yaşlılara Yönelik Sosyal Politikalar. Türkiye Fiziksel Tip ve Rehabilitasyon Dergisi, 56, 30-33.

Khorshıd, L., Akın, E. (2007). Mekanik Ventilatöre Bağlı Hastalarda Anksiyete Yönetiminde Müzikle Tedavinin Yeri. Yoğun Bakım Hemşireliği Dergisi, 11(2), 83-88.

Kirkwood, T. B. (2008). A Systematic Look at an Old Problem. Nature, 7;451(7179), 644-647.

Kocataş, S., Güler, G., Güler, N. (2004). 60 Yaş Ve Üzeri Bireylerde Depresyon Yaygınlığı. Atatürk Üniversitesi Hemşirelik Yüksekokulu Dergisi, 7(1), 11-18.

Koç, M. (2002). Gelişim Psikolojisi Açısından Yaşlılık Döneminde Ruhsal Döneminde Ruhsal Gelişim. Uludă̆ Üniversitesi Sosyal Bilimler Enstitüsü Dergisi, 12.

Kutsal, G. Y. (2008). Yaşlılık Döneminde Sık Görülen Sağlık Sorunları. Yaşlılıkta Kaliteli Yaşam. Hacettepe Üniversitesi Geriatrik Bilimler Araştırma ve Uygulama Merkezi(GEBAM). www.gebam.hacettepe.edu.tr.Ankara.

Morgan Clifford, T. (2006). Psikolojiye Giriş. Çev: H. Arıcı ve Ark. 17. Baskı, Ankara: Meteksan Yayınlar1.

Sezer, F. (2011). Öfke ve Psikolojik Belirtiler Üzerine Müziğin Etkisi. Uluslararası İnsan Bilimleri Dergisi, 8, 1472-1493.

Sung, H. C., Lee, W. L., Li, T. L., et al. (2012). A Group Music İntervention Using Percussion İnstruments with Familiar Music to Reduce Anxiety and Agitation of İnstitutionalized Older Adults with Dementia. Int J Geriatr Psychiatry, 27, 621-627. 
Verrusio, W., Andreozzi, P., Marigliano, B., et al. (2014). Exercise Training and Music Therapy in Elderly with Depressive Syndrome: 614-620.

WHO, "Ageing and Health", http://www.who.int/mediacentre/factsheets/fs404/en/, Erişim Tarihi 5 Kasim 2018.

WHO, The Uses of Epidemiology in the Study of the Elderly. WHO, Technical Reports Series 706, Geneva, 1984, 8-9.

World Health Organization, Men, Ageing and Health, 01WHO/NMH/ NPH 01.2 1999, Geneva.

Yener Alkaya, Y. (2011). Müziğin Çocuklar ve Yaşlılar Üzerindeki Etkileri. Pamukkale Üniversitesi Eğitim Fakültesi Dergisi, 29, 119-124.

Yüksel, N. (1998). Yaşlılık çağı depresyonları, Turkish Journal of Geriatrics, 1 (1), 19-23. 